\title{
PANCASILA DI DALAM PEMBUKAAN UUD 1945 BUKAN GRUNDNORM
}

\author{
Yogi Sumakto \\ Fakultas Hukum Universitas Yarsi \\ Email : mpuyogi@yahoo.com
}

\begin{abstract}
Pancasila (Five Principles) has been popularly known as the basic norm (Grundnorm) in Indonesia's legal order as well as in Indonesia's legal norm system. In fact, Pancasila has often been claimed as the source of origin of Indonesia's entire norms of life, including ethical norms, moral norms, etc. Such a view finds its strongest supporters in two of Indonesia's most prominent legal scholars: Roeslan Saleh and A. Hamid S. Attamimi. The paper attempts to deconstruct this established assumption. Retracing the theoretical concept of basic norm to the original source, which is none other than the thought of Hans Kelsen, the paper found that Pancasila cannot be classified as a basic norm. It turns out that the claim that Pancasila is a basic norm fails to meet the four criteria that Kelsen has outlined. First, a basic norm is not a norm 'established' by any highest legal organ. Second, basic norm is not a natural law. Third, basic norm gives objective legality to norms of the constitution without being dependent on the contents of the norms. Fourth, basic norm should conclude the hierarchy of norms. Therefore, the paper concludes that Pancasila is not a basic norm. Instead, Pancasila as it is contained in the Preamble to the 1945 Constitution should be classified as a positive law since it is established by a legal organ as well as a natural law due to its nature as principles that become the highest source of lower legal products.
\end{abstract}

Keywords : basic norm (Grundnorm), positive law, natural law, Pancasila (Five Principles)

\begin{abstract}
Abstrak
Pancasila selama ini terlanjur dikenal sebagai norma dasar (Grundnorm) dalam tertib hukum Indonesia dan sistem norma hukum Indonesia . Bahkan lebih dari itu, Pancasila tidak hanya menjadi sumber asal suatu tertib hukum, tetapi juga sumber asal dari seluruh norma-norma kehidupan bangsa Indonesia, termasuk etika, moral, dan lain sebagainya. Pandangan ini terutama dibela keras oleh dua tokoh hukum Indonesia, Roeslan Saleh dan A. Hamid S. Attamimi. Tulisan ini berupaya membongkar asumsi yang sudah beruratakar tersebut. Dengan menelusuri langsung ke sumber teoretis konsep Grundnorm, yaitu pemikiran Hans Kelsen, tulisan ini menemukan bahwa Pancasila tidaklah masuk ke dalam kategori Grundnorm jika merujuk pada pemikiran asli Kelsen. Klaim Pancasila sebagai norma dasar ternyata tidak mampu memenuhi empat kriteria norma dasar Kelsen. Pertama, norma dasar bukanlah norma yang “ditetapkan". Kedua, norma dasar
\end{abstract}


bukan hukum kodrat. Ketiga, norma dasar memberikan keabsahan obyektif kepada norma-norma dari konstitusi tanpa terikat kepada isi norma-norma tersebut. Keempat, norma dasar harus menutup hierarki norma. Oleh karena itu, tulisan ini menyimpulkan bahwa Pancasila bukanlah norma dasar sebagaimana sudah diyakini luas selama ini. Pancasila yang terkandung di dalam Pembukaan UUD 1945 justru lebih tepat dikatakan sebagai hukum positif karena sifatnya yang ditetapkan dan hukum kodrat (natural law) karena wataknya sebagai prinsipprinsip sumber bagi produk-produk hukum di bawahnya.

Kata kunci : norma dasar (Grundnorm), hukum positif, hukum kodrat, Pancasila (lima prinsip).

\section{A. Pendahuluan}

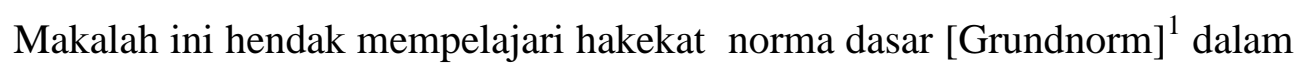
teori hukum Hans Kelsen: sebagai sebuah upaya menjernihkan persoalan kedudukan Pancasila ${ }^{2}$ qua [sebagai] Grundnorm di dalam struktur hirarkhi norma - norma sistem hukum Indonesia. Bertolak dari keinginan memperoleh kejelasan persoalan tersebut, tulisan ini terlebih dahulu mempelajari konsepsi Kelsen mengenai norma dasar (Grundnorm) sebagai bersifat hipotesis. ${ }^{3}$ Karena itu, tujuan pokok kajian ini adalah hendak mengkritisi dan menguji klaim dari

\footnotetext{
${ }^{1}$ Dalam teori Hukum, istilah "norma dasar" [Grundnorm] merujuk kepada "Grund" ["Sumber"] dari keabsahan hukum positif. Karena itulah, tujuan Kelsen dengan doktrin norma dasar-nya ialah: memungkinkan ilmuwan hukum menjawab penelitian pada "Grund" dari keabsahan sebuah konstitusi hukum positif dan sistem hukum yang berlandaskan kepada konstitusi itu - Pertanyaan kenapa sebuah konstitusi tertentu dilihat sebagai suatu sistem yang terdiri dari norma-norma sah dan mengikat. Dalam pandangan Kelsen, meneliti "Grund" dari keabsahan hukum, sama halnya dengan menanyakan kenapa hukum itu sah. Jawaban yang ditawarkan seperti dinyatakan Kelsen sebagai berikut: "Grund" dari hukum yang sah ialah: norma dasar sebuah norma terakhir [ultimate], norma yang dipikirkan yang menyatakan bahwa konstitusi [dan sistem hukum yang bersandar kepadanya] harus dilaksanakan - bahwa konstitusi dan sistem hukum itu merupakan hukum yang sah dan mengikat. Atau, dengan kata lain: "hukum itu sah dan mengikat karena norma dasar menyatakan demikian [yaitu, jika norma dasar itu diandaikan]. Lihat Uta Bindreiter, Why Grundnorm?: A Treatise on the Implications of Kelsen's Doctrine. The Hague, Nederlands: Kluwer Law International, 2002, hal. 15.

${ }^{2}$ Ir. Soekarno (Bung Karno) pertama kali mencetuskan idea Pancasila sebagai usul mengenai dasar filsafat negara [Philosofische grondslag] Indonesia Merdeka, yang diucapkan dalam sidang Badan Penyelidik Usaha Persiapan Kemerdekaan [BPUPK] pada tanggal 1 Juni 1945. Lihat Muh. H. Yamin, Naskah Persiapan Undang-Undang Dasar 1945. Jilid I. Jakarta: Prapanca, 1959, Cetakan kedua 1971.

${ }^{3}$ Dalam pengertian ini istilah "Grundnorm" dipakai sepanjang karya Kelsen, di mana Grundnorm didefinisikan sebagai sebuah norma hipotesis atau fundamental - sebuah norma yang diasumsikan. Kelsen berpendapat bahwa keharusan menetapkan keabsahan (validity) satu norma dengan melacaknya kembali kepada keabsahan dari satu norma yang lebih tinggi tidak bisa terus berlanjut tanpa batas [ad infinitum] dan harus berakhir pada satu titik. Titik akhir ini, harus dianggap sebagai dasar keabsahan norma yang mempunyai tingkatan lebih rendah, ialah Hypothesis dari norma dasar. Lihat, Geert Edel, "The Hypothesis of the Basic Norm: Hans Kelsen dan Herman Cohen," Normativity and Norms: Critical Perspectives on Kelsenian Themes, eds. Stanley L. Paulson dan Bonnie Litschewski Paulson. Oxford: Clarendon Press, 1998, hal. 213.
} 
berbagai kalangan hukum di Indonesia bahwa Pancasila merupakan Grundnorm di dalam struktur hirarkhi norma-norma sistem hukum Indonesia; ${ }^{4}$ yakni, benarkah Pancasila itu adalah Grundnorm atau bukan? Untuk itu, makalah ini akan dimulai dengan melakukan kajian terhadap konsep Kelsen mengenai norma dasar [Grundnorm] sebagai inti Teori Murni Hukum dalam memungkinkan memberi kejelasan persoalan kedudukan Grundnorm itu sendiri.

Dalam mempelajari teori Kelsen tersebut, perhatian perlu diarahkan pada pemahaman yang lebih lengkap mengenai epistemologi hukum dalam perkembangan Teori Murni Hukum. ${ }^{5}$ Tetapi, kajian ini lebih difokuskan pada teori norma dasar Kelsen; karena tujuan Kelsen membangun Teori Murni Hukum ialah ingin menciptakan teori umum dengan mengkonstruksi konsep "hukum dasar"-nya "secara eksklusif" dari isi [materi / substansi] norma-norma hukum. Dengan mengacu kepada konsep norma dasar Kelsen ini, pembahasan dilanjutkan dengan menguji klaim bahwa Pancasila merupakan norma dasar [Grundnorm]. Di sini perlu sekali lagi ditegaskan, tujuan pokok kajian ini ialah mengkritisi dan menguji benarkah klaim bahwa Pancasila di dalam Pembukaan UUD 1945,

\footnotetext{
${ }^{4}$ Pemikiran Pancasila merupakan norma dasar [Grundnorm] dalam sistem norma hukum di Indonesia bisa dipelajari, misalnya dari pernyataan Roeslan Saleh, Penjabaran Pancasila dan UUD' 45 dalam PerundangUndangan. Jakarta: Sinar Grafika, 1979; dan pernyataan A. Hamid S. Attamimi, "Peranan Keputusan Presiden Republik Indonesia dalam Penyelenggaraan Pemerintahan Negara: Suatu Studi Analisis mengenai Keputusan Presiden yang Berfungsi Pengaturan dalam Kurun Waktu Pelita I - Pelita IV.” Disertasi Fakultas Pascasarjana Universitas Indonesia, 1990. Tetapi pernyataan dan penafsiran Pancasila sebagai norma dasar [Grundnorm] merupakan suatu kesalahan yang lazim dilakukan oleh berbagai kalangan di Indonesia.

${ }^{5}$ Perkembangan detail teori Murni Kelsen secara kronologis dapat dibedakan menjadi tiga fase utama, yaitu: pertama, fase awal, konstruktivisme kritis (1911-21), kemudian, fase klasik (circa 1921-1960); menurut Paulson, "fase klasik" ini dikenal sebagai fase yang panjang, terbagi menjadi periodisasi neo-Kantian (1922-1935) dan hybrid (1935-1960). Terakhir, fase skeptis (1960-1973). Untuk rangkaian pendapat mengenai "pertanyaan-pertanyaan periodisasi", lihat misalnya Stanley L. Paulson, "Four Phases in Hans Kelsen's Legal Theory? Reflections on a Periodization", Oxford Journal of Legal Studies, 18, 1998, hal.153-66. Meskipun demikian, tidak ada kesepakatan umum mengenai masalah periodisasi perkembangan teori hukum Kelsen ini, karena itu pendapat Paulson bukan satu-satunya yang menggambarkan perkembangan teori itu, setidaknya masih bisa diperhatikan pendapat Carsten Heidemann, yang membagi menjadi empat fase, yaitu (1) Konstruktivist (1911-1915), lalu diikuti dengan fase transisi (1915-1922); (2) fase transendental (1922-1935); (3) fase realist (1935-1962), dan terakhir, fase analitiklinguistis (setelah 1962). Lihat Paulson, "Four Phases", 1998, hal. 161. Eugeno Bulygin memisahkan posisi Kantian dan positivis dalam pemikiran Kelsen dengan membedakan: Fase pertama, elemen-elemen Kantian dan positivistis tampak hadir bersama berdampingan dengan harmonis, dan Kelsen tampaknya tidak menyadari pertentangan di antara keduanya. Fase ini berjalan kira-kira 30 tahun pertama karya filosofisnya (1911-1940); fase kedua, fase transisional berjalan sekitar 20 tahun (1940-1960), dan terakhir, fase yang secara dominan positivistis (setelah 1960); Lihat Eugeno Bulygin, "An Antinomy in Kelsen's Pure Theory of Law," Ratio Juris, 3, 1990, hal. 29-45.
} 
mempunyai kedudukan sebagai norma dasar [Grundnorm] dalam sistem norma hukum Indonesia?

\section{B. Doktrin Norma Dasar Kelsen}

Teori Murni Hukum kerapkali dinisbatkan kepada tradisi positivistis dan tradisi pemikiran neo-Kantian. ${ }^{6}$ Untuk itu, epistemologi hukum Kelsen dalam perkembangan Teori Murni Hukum tidak dapat dilepaskan dari pengaruh tradisi positivistis dan tradisi Kantian tersebut. Kecenderungan tradisi filosofis yang berbeda dalam pemikiran Kelsen ini tidak hanya sulit didamaikan, tetapi juga sangat bertolak belakang [bertentangan] secara radikal satu sama lain. Karena bertentangan, sejumlah idea Kelsen yang berasal dari salah satu tradisi ini harus dihilangkan [diabaikan] dalam rangka menjadikan Teori Murni Hukum yang utuh. Tradisi manakah yang dipertahankan Kelsen, itu harus ditelusuri konstruksi pemikiran Kelsen sehingga ditemukan apakah pandangan positivistis atau pandangan Kantian menjadi pilihan ini.

Ketika itu, awal 1920-an menandai permulaan Teori Murni Hukum. Teori Kelsen dalam bentuk seperti itulah yang lazim dikenal. Adalah fakta bahwa sejak pertama kali teori itu diperkenalkan elemen - elemen dari tradisi Kantian dan tradisi positivistis sudah mempengaruhi Teori Murni Hukum. Dalam hubungan ini, pertama Kelsen memperkenalkan doktrin-doktrin Kantian dalam fase klasik adalah fundamental. Kedua, pada 1923 Kelsen pun mengadopsi doktrin Adolf Julius Merkl mengenai struktur hirarkhis norma hukum [Stufenbaulehre] qua teori dinamika hukum, yakni sebuah teori dari Merkl yang diadopsi Kelsen dimasukkan

\footnotetext{
${ }^{6}$ Lihat Bulygin, “An Antinomy,” 1998, hal. 299-300., menjelaskan ide-ide utama Kelsen yang memiliki asal-usul Kantian yakni: [1] pencirian norma-norma hukum sebagai entitas ideal yang berada dalam dunia sollen (ought), yang berbeda dari dunia realitas alam atau dunia sein (is); [2] konsepsi keabsahan qua kekuatan mengikat; [3] normativitas ilmu hukum; dan [4] doktrin terkenal Kelsen mengenai norma dasar sebagai kategori transendental. Bulygin mengatakan bahwa semua tesis ini terkait satu sama lain. Adapun ideal Kelsen mengenai ilmu hukum positivistis berkaitan dengan empat tesis fundamental, yakni: [5] pemisahan tajam antara "senyatanya" dan "seharusnya"; [6] konsepsi non-kognitivis mengenai norma dan pertimbangan nilai sebagai preskripsi-preskripsi yang tidak benar dan juga tidak salah; [7] positivitas hukum, tesis bahwa semua hukum itu positif, yaitu diciptakan dan dihancurkan oleh tindakan-tindakan terutama manusia, atau - norma-norma hukum menjadi ada atau lenyap sebagai akibat dari tindakan tertentu manusia; dan [8] pemisahan tajam antara deskripsi dan preskripsi (atau evaluasi) antara rasio dan kehendak, antara kognisi hukum dan penciptaan hukum, antara ilmu hukum dan politik hukum.
} 
ke dalam Teori Murni Hukum. ${ }^{7}$ Dengan mengadopsi doktrin Merkl ini, Kelsen mulai meninggalkan pandangan hukum statis - doktrin ini pun menjanjikan pandangan hukum dinamis, ${ }^{8}$ yang berpengaruh dalam menjelaskan sifat dinamis dari hukum dan pemberian kekuasaan dari norma dasar, ${ }^{9}$ sedangkan pengaruh tradisi Kantian merupakan faktor lain yang menjelaskan pendasaran transendental dari teori Murni, karena itu norma dasar berfungsi sebagai pengandaian ilmu hukum yang perlu - dan harus bersifat hipotesis.

Kelsen berkepentingan sekali mengajukan konsepsi (tesis) "norma dasar" ["Grundnorm"], sebagai mendasari keabsahan obyektif dari hukum. Penekanan kepada persoalan "mencari pendasaran” keabsahan obyektif dari hukum, bagi Kelsen adalah dalam rangka memberi "Grund" ("sumber" atau "dasar") dari keabsahan sebuah konstitusi dan sistem hukum tertentu - sebagai sebuah sistem yang terdiri dari norma-norma sah dan mengikat. Dalam pandangan Kelsen, meneliti "Grund" dari keabsahan hukum berarti sama dengan menanyakan

\footnotetext{
${ }^{7}$ Kelsen mengidentifikasi dirinya sendiri dengan doktrin Merkl pada 1920, tetapi pernyataan mengenai struktur hirarkhi norma hukum (Stufenbaulehre) yang lengkap di tangan Kelsen sendiri ditemukan dalam makalah panjang pada 1923. Adapun idea umum Merkl tersebut adalah hukum mengatur penciptaannya sendiri, terutama norma hukum yang mengatur prosedur dengan menggunakan norma-norma hukum, kemudian norma-norma hukum yang lain ditetapkan. Lihat, Stanley L. Paulson, "Introduction," Normativity and Norms: Critical Perspectives on Kelsenian Themes, eds. Stanley L. Paulson dan Bonnie Litschewski Paulson. Oxford: Clarendon Press, 1998, hal. xxv-xxvi.

${ }^{8}$ Dalam teori hukum Kelsen, ditemukan dua prinsip dasar yang berbeda. Pertama, prinsip statis ("Nomostatics") dan, kedua prinsip dinamis ("Nomodynamics"). Tergantung pada jenis norma dasarnya, kedua tertib tersebut normatif dibedakan: yakni, tertib normatif statis dan tertib normatif dinamis. Norma dasar tertib normatif statis dianggap sah karena isinya; norma-norma yang membentuk macam tertib normatif statis ini dideduksi dari isi [substansi] norma dasarnya. Di pihak lain, tertib normatif dinamis mempunyai prinsip yang berbeda secara radikal dan bertentangan dengan prinsip konstitutif dari tertib normatif statis. Norma-norma tertib normatif dinamis tidak sah karena isi (substansi)-nya, dan norma yang membentuk tertib tersebut tidak dapat dideduksi dari norma dasarnya. The only content of this norm is the means of determining the acts through which other norms are created. Lihat Hans Kelsen, Pure Theory of Law. Diterjemahkan oleh Max Knight, Berkeley, Los Angeles, London: University of California Press, 1967, hal. 56. Hukum merupakan tertib normatif dinamis. Lihat, Ulises Schmill, "The Dynamic Order of Norms: Empowerment and Related Concepts," Law and Philosophy, Vol. 19, No. 2, Kelsen, Authority, and Competence (Mar., 2000), hal. 283-285.

${ }^{9}$ Perkembangan pemikiran ini, menandai kepentingan Kelsen dalam masalah law making (pembuatan hukum). Kepentingan itu direfleksikan inter alia [antara lain] pada masalah-masalah sifat sistem hukum pada umumnya dan khususnya pada peranan empowerment (pemberian kekuasaan). Lihat, Stanley L. Paulson, "Introduction," hlm. xlvii-xlviii. Kelsen setidak-tidaknya pada fase klasiknya ini menunjukkan tiga doktrin pokok mengenai pemberian kekuasaan (hukum). Pertama, doktrin struktur hirarkhi (Stufenbaulehre) memperlengkapi pandangan pembuatan hukum - menentukan watak hukum dinamis, kembali pada idea pemberian kekuasaan sebagai alat yang khas pengeluaran norma-norma, yakni mengenai penciptaan hukum. Kedua, konsep konstitusi Kelsen identik dengan seperangkat peraturan dalam pembentukan hukum - secara singkat seperangkat norma yang memberi kekuasaan. Ketiga, konstitusi logis (the Constitution in a logical sense) Kelsen - norma dasar - dipahami dengan tepat dalam sejumlah konteks seperti mempunyai bentuk norma yang memberi kekuasaan.
} 
"kenapa" hukum itu sah. Hukum itu sah dan mengikat karena norma dasar mengatakan demikian, yaitu norma dasar itu diandaikan. ${ }^{10}$ Dengan pengandaian "norma dasar" ini memungkinkan Kelsen berbicara mengenai "hukum yang sah". Pengandaian perlu sebagai konsepsi yang dimaksudkan memahami hukum sebagai satu kesatuan sistem norma-norma hukum yang mengikat. Pengandaianpengandaian tersebut mendasari Teori Murni Hukum dan sekaligus menetapkan klaim hukum positif atas keabsahan yang diambil dari hukum positif itu sendiri.

Tetapi upaya Kelsen itu menghadapi berbagai persoalan yang berasal dari konstelasi rumit yang masih mengitari Teori Murni Hukum, terutama berkaitan dengan permasalahan norma dasar Kelsen yang berasal dari tradisi Kantian. Persoalan menetapkan keabsahan sebagai kekuatan mengikat yang sesuai dengan konsepsi positivistis dari ilmu hukum dengan rujukan kepada norma dasar masih tidak memuaskan. Karena itu, teori norma dasar selalu memperoleh kecaman dan penolakan dari berbagai kalangan hukum. ${ }^{11}$ Kecaman itu dipicu oleh ketidakmampuan Kelsen menjelaskan norma dasar yang dinilai oleh ilmuwan hukum sebagai konsepsi yang mengacaukan bagi suatu sistem hukum. Kepada berbagai kalangan lain, Kelsen tidak mampu menjelaskan terutama mengenai "status" dan "cara" norma dasar itu diandaikan. Apakah "norma dasar" hanya merupakan asumsi konseptual atau norma yang sejati dan mengikat? Tetap tidak begitu memberi kejelasan mengenai "status" norma dasar tersebut. Kelsen sendiri menyatakan ini telah tampak jelas setidaknya bagi dirinya sendiri. Kelsen bahkan tetap dengan pernyataannya bahwa istilah "Grundnorm" telah tepat digunakan sebagai pengertian yang memberi pendasaran kepada Teori Murni Hukum.

Keadaan sulit yang dihadapi Kelsen ini lazimnya berkenaan dengan "status" norma dasar yang memang dikelilingi dengan keruwetan persoalan keabsahan

\footnotetext{
${ }^{10}$ Bindreiter, Why Grundnorm? 2002, hal. 15.

${ }^{11}$ Chhatrapati Singh, Law From Anarchy to Utopia. Oxford: Clarendon Press, 1986, hal. 103. Kelsen mengatakan kepada kita landasan Grundnorm dari hukum merupakan sebuah "pengandaian transendental logis", tetapi dalam pengertian transendental macam apakah proposisi "kita harus bertingkah laku sebagaimana ditetapkan konstitusi", - atau menurut bahasa Kelsen, dalam pengertian apa "kita harus bertingkah laku" menurut perintah dari otoritas pencipta konstitusi - menurut Chhatrapati Singh, bisakah itu dikatakan sebagai proposisi transendental?
} 
norma dasar itu sendiri. ${ }^{12}$ Persoalan keabsahan norma dasar itu sulit dipecahkan, karena Kelsen taat pada doktrin pengandaian, sedangkan selain itu ia masih menginginkan menjadi positivist hukum. Penolakan terhadap argumen Kelsen karena perkawinan ini sebagai ketidakkonsistenan radikal dalam teori Murni. Ketidakkonsistenan radikal antara doktrin pengandaian dan positivisme hukum dalam Teori Murni Hukum secara prinsip lahir ketika Kelsen mengusulkan pemecahan persoalan keabsahan hukum qua kekuatan mengikat melalui doktrin pengandaian, di satu pihak, dan cara di mana Kelsen mengusulkan kesesuaiannya dengan positivisme hukum, di pihak lain. ${ }^{13}$

\section{Pancasila bukan norma dasar [Grundnorm] dari Kelsen}

Konsep mengenai norma dasar Kelsen ini di Indonesia mendapat perhatian dari berbagai kalangan hukum dengan mengkaitkan doktrin tersebut dengan Pancasila. Apakah mereka [para ilmuwan hukum di Indonesia] menyadari atau tidak persoalan yang mengitari norma dasar ini; ketika mereka menggunakan (atau tepatnya mengadopsi) pandangan Kelsen mengenai doktrin Grundnorm yang bersifat hipotetis tersebut, yakni hanya diandaikan oleh pemikiran manusia ini sebagai landasan mengembangkan sistem hukum nasional, yakni dengan menempatkan kedudukan Pancasila qua norma dasar di dalam struktur hirarkhi norma-norma sistem hukum Indonesia.

Dalam makalah ini hendak diupayakan memahami persoalan ini dengan mengemukakan beberapa pendapat ilmuwan hukum yang mengkonstruksi Pancasila sebagai norma dasar [Grundnorm] demi kepentingan pembentukan hukum nasional kita. Roeslan Saleh misalnya berpendapat, yaitu:

"bahwa ada yang positif dari teori Kelsen ini yang dapat digunakan untuk kepentingan pembentukan hukum nasional kita dan penerapannya. Kami juga tidak ingin menunjukkan sekilas bahwa menurut teori hukum bukanlah mustahil untuk mengkonstruksikan Pancasila dalam rangka pandangan ini.

\footnotetext{
${ }^{12}$ Penjelasan Kelsen tetap menimbulkan keruwetan dan ketidakjelasan, karena sikap Kelsen mengenai norma dasar yang kerapkali berubah-ubah. Dalam berbagai tulisan, Kelsen merumuskan norma dasar dengan sejumlah cara yang berbeda. Uta U. Bindreiter dengan merujuk kepada Stanley L. Paulson mencatat sepuluh cara berbeda dari Kelsen dalam merumuskan norma dasar. Lihat, Uta U. Bindreiter, "Presupposing the Basic Norm," Ratio Juris, Vol. 14, No. 2 (June, 2001), hal. 144.

${ }^{13}$ Bulygin, “An Antinomy," 1998, hal. 315.
} 
Perihal kesatuan yuridis ini hanyalah satu dari banyak pengertian-pengertian dasar yang bersifat elementer, dengan mana lalu dapat dibangun pengertianpengertian dasar yang lebih kompleks lagi. ${ }^{14}$

Roeslan Saleh berupaya menjelaskan teori hukum Kelsen, diikuti dengan langkah-langkah mengkonstruksi Pancasila dalam ketunggal-ikaan yuridis dalam kebhinekaan norma-norma dalam tertib hukum Indonesia; yakni, dengan mengadopsi doktrin Grundnorm Kelsen sebagai Pancasila seperti berikut ini: "Bahkan dilihat dari kedudukan Pancasila dalam Pembukaan Undang - Undang Dasar, menurut hemat kami pengertiannya sebagai Grundnorm akan mencakup hal-hal yang lebih luas dari yang dimaksudkan oleh KELSEN, Jika KELSEN berpendapat bahwa Grundnorm yang bersifat ilmiah dan hipotetis itu adalah sumber asal dari tertib hukum, menurut hemat kami, dengan penempatan Pancasila dalam Preamble, dan memperhatikan pula perumusan fungsi dalam Preamble tersebut, ia merupakan Grundnorm tidak hanya dari norma-norma hukum, tetapi dari seluruh norma-norma kehidupan bangsa Indonesia (ethik, moral dan sebagainya)."15

Pendirian Roeslan Saleh ini kembali ditegaskan dengan mengatakan bahwa dalam susunan tertib kehidupan Indonesia hukum dan moral itu dapat dibedakan, tetapi tidak terpisahkan, melainkan satu tunggal dalam Grundnorm Pancasila. ${ }^{16}$ Pernyataan Pancasila merupakan satu norma dasar [Grundnorm] seperti disebutkan Roeslan Saleh tersebut memperoleh perhatian dari, misalnya oleh A.

\footnotetext{
${ }^{14}$ Roeslan Saleh, "Pembinaan Cita Hukum dan Penerapan Azas-azas Hukum Nasional.” Majalah Hukum Nasional, Jakarta, Badan Pembinaan Hukum Nasional Departemen Kehakiman, edisi khusus No. 1 Tahun 1995, hal. 57.

${ }^{15}$ Saleh, Penjabaran Pancasila, 1979, hal. 43.

${ }^{16}$ Saleh, Penjabaran Pancasila, hlm. 44-45. Dengan merujuk kepada stufentheorie dari Kelsen, Saleh mengkonstruksi Pancasila dalam tertib hukum Indonesia sebagai berikut:

1. Pancasila adalah suatu Grundnorm (norma dasar), bagi kehidupan bangsa, masyarakat dan negara Indonesia. Ia lebih luas daripada yang dikemukakan oleh Kelsen yang membahas Grundnorm hanya sebagai norma dasar dari suatu tertib hukum. Oleh karenanya pula, jika lazimnya orang mengemukakan ketunggal-ikaan yuridis dalam ke-bhineka-an norma-norma hukum, dengan Pancasila kita dapat (dan harus mengkonstruksikan) ketunggal-ikaan dalam ke-bhineka-an norma-norma;

2. Pancasila bukan hanya norma dasar dari kehidupan hukum dan tertib hukum Indonesia, tetapi adalah juga norma dasar dari norma-norma lain, seperti norma moral, norma kesusilaan, norma ethika, dan sebagainya;

3. Pancasila mengharuskan tertib hukum Indonesia juga serasi dengan norma-norma moral, kesusilaan, ethika, dan sebagainya, oleh karena di dalam Pancasila terkandung pula norma-norma tersebut.
} 
Hamid S. Attamimi, ketika ia mempertahankan disertasi ilmu hukum di hadapan Senat Guru Besar Universitas Indonesia, 1990 mengemukakan sebagai berikut: “ oleh karena itu sila-sila dalam Pancasila, baik sendiri-sendiri maupun bersamasama, baik tunggal maupun berpasangan, merupakan norma dasar atau norma tertinggi bagi berlakunya semua norma - norma hukum yang berlaku dalam kehidupan rakyat Indonesia bermasyarakat, berbangsa, dan bernegara." ${ }^{11}$

Bahkan dalam tulisan yang lain, A. Hamid S. Attamimi menyatakan dengan tegas Pancasila yang dimaksud itu ialah Pancasila di dalam Pembukaan UUD 1945, seperti berikut ini: “ - UUD 1945 semestinya tidak termasuk dalam kategori Peraturan Perundang-undangan seperti dimaksudkan oleh TAP MPR No. XX/MPR/1966, melainkan termasuk norma dasar [Grundnorm], yakni pembukaannya, dan termasuk aturan dasar [Grundgesetze], yakni Batang Tubuhnya. - maka berdasarkan hal-hal di atas tata susunan norma hukum yang tepat ialah berturut-turut: norma dasar, yakni Pancasila dalam Pembukaan UUD 1945; Aturan Dasar, yakni Batang Tubuh UUD 1945, dan baru di bawahnya undang-undang sebagai jenis tertinggi dari peraturan perundang-undangan."

Pernyataan tersebut dengan tegas menyebutkan Pancasila adalah norma dasar di dalam sistem norma hukum Indonesia. Pancasila dikatakan sebagai norma dasar [Grundnorm], yakni istilah norma dasar yang diperkenalkan Kelsen. Pernyataan Roeslan Saleh dan A. Hamid S. Attamimi ini tetap membingungkan, karena pengertian norma dasar Kelsen sebagai pengandaian yang perlu dan bersifat hipotetis - berbeda sekali dengan pengertian Pancasila yang dikemukakan Bung Karno pada tanggal 1 Juni 1945; kemudian oleh Roeslan Saleh dan A. Hamid S. Attamimi ditafsirkan sebagai norma dasar [Grundnorm] di dalam sistem norma hukum Indonesia. Pernyataan Pancasila qua Grundnorm dari Roeslan Saleh dan A. Hamid S. Attamimi inilah menjadi perhatian utama kajian ini. Apakah benar Pancasila merupakan Grundnorm dalam struktur hirarkhi norma-norma

\footnotetext{
${ }^{17}$ Attamimi, "Peranan Keputusan," 1990, hal. 333.

${ }^{18}$ Attamimi, "UUD 1945, TAP MPR, Undang - Undang," Masalah Ketatanegaraan Indonesia Dewasa Ini. Dihimpun oleh Padmo Wahyono. Jakarta: Ghalia Indonesia, 1984, hal. 129-130.
} 
sistem hukum di Indonesia? Pertanyaan ini perlu penjelasan ilmiah berdasarkan ilmu pengetahuan.

Bung Karno di hadapan sidang BPUPK pada tanggal 1 Juni 1945 sebenarnya menyampaikan sejumlah prinsip yang disebut Pancasila, bukan doktrin norma dasar [Grundnorm] dari Kelsen. Ketika itu, Bung Karno mengemukakan prinsip-prinsip Pancasila sebagai Philosofische grondslag dari Indonesia Merdeka." "Sila artinya azas atau dasar, dan di atas kelima dasar itulah, kita mendirikan Negara Indonesia, kekal dan abadi.” Bung Karno, melanjutkan: "Isinya telah saya katakan kepada saudara-saudara semuanya. Prinsip-prinsip yang saya usulkan kepada saudara-saudara ini, adalah prinsip untuk Indonesia Merdeka yang abadi." ${ }^{20}$ Kemudian, pada tanggal 18 Agustus 1945, PPKI meletakkan secara formal Pancasila di dalam Pembukaan UUD 1945. Dilihat dari segi hukum formil, "Preamble" (Pembukaan) tempatnya terpisah dari suatu konstitusi; di Indonesia, misalnya dikenal sebutan Pembukaan UUD 1945. "Pembukaan" ini ditempatkan di depan dari suatu konstitusi, oleh karena itu ia ditafsirkan sebagai tidak penting karena kehadirannya hanya sekadar

\footnotetext{
${ }^{19}$ Ketika itu, pertanyaan "Kaityo" (Ketua) "Dokuritsu Zyunbi Tyoosakai” (Badan Penyelidik Usaha Persiapan Kemerdekaan/ BPUPK), dr. K.R.T. Radjiman Wediodiningrat dijawab oleh Bung Karno dengan mengatakan: 'Paduka Tuan Ketua Minta dasar, minta 'Philosofische grondslag' atau, jikalau kita boleh memakai perkataan yang muluk-muluk, Paduka Tuan Ketua yang mulia meminta suatu 'Weltanschauung', di atas mana kita mendirikan negara Indonesia itu - namanya ialah Pancasila.” Bagi Bung Karno Philosofische grondslag ini merupakan fondamen, filsafat, pikiran yang sedalam-dalamnya, jiwa, hasrat yang sedalamdalamnya untuk di atasnya didirikan gedung Indonesia Merdeka yang kekal dan abadi. Lihat Soekarno, Pancasila sebagai Dasar Negara. Jakarta: Diterbitkan atas Kerja sama Inti Idayu Press - Yayasan Pendidikan Soekarno, 1986, hal. 133-158, pada hal. 133, 140, 154.

${ }^{20}$ Soekarno, Pancasila. 1986, hal. 154-155.

${ }^{21}$ Pembukaan Undang-Undang Dasar 1945 [selanjutnya disebut, Pembukaan UUD 1945], kita kenal sebagai jiwa UUD 1945 karena Pembukaan UUD 1945 itu merumuskan tujuan dan cita-cita dari bangsa Indonesia Merdeka. Bahkan selain itu, pada Alinea keempat dari empat Alinea yang terdapat di dalam Pembukaan UUD 1945 itu telah dicantumkan lima prinsip yang kemudian lazim dikenal dengan sebutan Pancasila seperti pertama kali diucapkan sebagai "Filsafat Dasar Negara" ["Filosofische Grondslag"] oleh Ir. Soekarno. Istilah Pancasila itu sendiri tidak dijumpai di dalam Pembukaan UUD 1945, namun kata Pancasila itu baru muncul secara tegas di dalam Pasal 36A UUD 1945 hasil Amanden ke-2. Ketentuan Pasal 36A tersebut menyebutkan "Lambang Negara ialah Garuda Pancasila..." Penyebutan kata Pancasila dinisbatkan dengan lambang negara di dalam Pasal 36 A tersebut, bisa ditafsirkan bahwa lima prinsip seperti disebutkan di dalam Alinea keempat Pembukaan UUD 1945 itu dapat dimaksudkan sebagai Pancasila. Bahkan Jimly Asshiddiqie menegaskan bahwa lima prinsip yang terkandung dalam Pembukaan UUD 1945 yang berdasarkan konvensi ketatanegaraan selama ini memang sudah disebut dengan nama Pancasila, menjadi resmi tercantum dalam Pasal 36 A ini namanya adalah Pancasila. Lihat Jimly Asshiddiqie, Komentar Atas Undang-Undang Dasar Negara Republik Indonesia Tahun 1945. Jakarta: Sinar Grafika, 2009, hal. 148.
} 
sebagai syarat bagi tuntutan keindahan penulisan naskah konstitusi. ${ }^{22}$ Karena dalam Pembukaan itu, berisi cita-cita dan tujuan dari konstitusi itu ditetapkan sehingga "Pembukaan" lazimnya lebih memiliki karakter ideologis daripada hukum. Tetapi dari segi hukum materiil (substansial), sila-sila dari Pancasila dalam Pembukaan UUD 1945 dapat dikatakan sebagai sumber hukum. Bila ditinjau dari ilmu hukum tradisional yang berkembang pada abad ke-19 dan ke20, Pancasila dapat menjadi sumber (pangkal tolak) dari tertib hukum di Indonesia. Dengan demikian, Pancasila di dalam Pembukaan UUD 1945 dilihat dari isinya adalah hukum kodrat (natural law), tetapi UUD 1945 itu sendiri tidak bisa disebut hukum kodrat, melainkan hukum positif (positive law) karena pada tanggal 18 Agustus 1945 ditetapkan PPKI (Panitia Persiapan Kemerdekaan Indonesia) sebagai sebuah organ hukum. ${ }^{23}$

Dengan ditetapkannya secara formal Pancasila di dalam Pembukaan UUD 1945 oleh sebuah badan yang disebut PPKI, berarti kedudukan Pancasila dalam Pembukaan UUD 1945 tersebut lebih tepat dikatakan sebagai hukum positif (positive law) dan bukan sebagai norma dasar [Grundnorm] seperti dilakukan Roeslan Saleh dan A. Hamid S. Attamimi. Karena dengan meletakkan Pancasila dalam Alinea ke-4 sebagai penutup dari Pembukaan UUD 1945, berarti Pancasila telah mempunyai makna formalnya: yakni, Pancasila secara formal telah ditetapkan di dalam Pembukaan UUD 1945 sebagai dasar negara Republik Indonesia oleh PPKI, sebuah organ hukum tertinggi yang memiliki otoritas menetapkan UUD 1945 pada tanggal 18 Agustus 1945.

Kedudukan Pancasila di dalam Pembukaan UUD 1945, telah ditetapkan secara formal oleh suatu organ hukum tertinggi, tidak tepat disebut sebagai norma

\footnotetext{
${ }^{22}$ Moh. Koesnoe, "Perumusan dan Pembinaan Cita Hukum dan Azas-azas Hukum Nasional," Majalah Hukum Nasional, Badan Pembinaan Hukum Nasional, Departemen Kehakiman, No. 2, 1995, hal. 70-118. Bandingkan pernyataan Moh. Koesnoe ini dengan pernyataan Kelsen bahwa "If it (preamble, pen) were dropped, the real import of the constitution would ordinarily not be changed in the least." Hans Kelsen, General Theory of Law and State. Diterjemahkan oleh: Anders Wedberg. Cambridge, Mass: Harvard University Press, 1945, hal. 260-261.

${ }^{23}$ Pernyataan ini sejalan dengan pandangan Andrew J. Reck, "Natural law and the Constitution," The Review of Metaphysics, Vol. 42, No. 3, Mar., 1989, hal. 485., yang mengatakan: "This is not to say that the Constitution is the natural law; it is obviously positive law, but positive law more fundamental than the laws enacted by Congress, the regulations of agencies, the executive orders of the President, the judgments and orders of the courts."
} 
dasar [Grundnorm] dari Kelsen. ${ }^{24}$ Karena, Kelsen sendiri menyatakan bahwa doktrin norma dasar tidak ditetapkan berdasarkan prosedur hukum, melainkan hanya diandaikan oleh pemikiran yuristis. Dengan demikian, klaim bahwa Pancasila adalah norma dasar [Grundnorm] dari Kelsen, seperti diutarakan Roeslan Saleh dan A. Hamid S. Attamimi jelas tidak berdasar sama sekali.

Kelsen menyatakan :

"The basic norm is not created in a legal procedure by a law-creating organ. It is not - as a positive legal norm is - valid because it is created in a certain way by a legal act [rather,] it is valid because it is presupposed to be valid, and it is presupposed to be valid because without this presupposition no human act could be interpreted as a legal, especially as a norm-creating act. $^{25}$

"Norma dasar tidak diciptakan dalam satu prosedur hukum oleh sebuah organ pembuat hukum. Norma dasar tidaklah - sebagaimana norma hukum positif itu sah - sah karena dibuat dalam cara tertentu oleh satu tindakan hukum, [sebaliknya,] ia sah karena ia diandaikan sebagai sah; dan ia diandaikan sebagai sah karena tanpa pengandaian ini, tidak ada tindakan manusia yang sah bisa diinterpretasikan sebagai tindakan sah, terutama sebagai tindakan pembuatan norma.

Meskipun demikian, rumusan sila-sila Pancasila di dalam Pembukaan UUD 1945, tidak ditetapkan sebagai suatu pasal atau norma hukum, melainkan hanya ditetapkan sebagai prinsip-prinsip Negara Indonesia Merdeka; maka kelima prinsip dari Pancasila memenuhi syarat sebagai prinsip - prinsip hukum yang lebih tinggi.

Kelsen mengatakan:

"A traditional part of the instruments called "constitutions" is a solemn introduction, a so - called "preamble" expressing the political, moral, and

\footnotetext{
${ }^{24}$ Dengan mengacu kepada doktrin terkenal Kelsen mengenai Grundnorm yang bersifat hipotetis, tidaklah cermat Pancasila dikonstruksi sebagai norma dasar (Grundnorm) dari Kelsen. Karena secara formal kedudukan Pancasila di dalam (Pembukaan) UUD 1945, berada di dalam tingkatan konstitusi; sedangkan kenapa UUD 1945 (konstitusi) tersebut sah (valid) tidak bisa dijawab dengan rujukan pada sebuah norma yang lebih tinggi, melainkan karena ditetapkan oleh sebuah organ hukum tertinggi yang diberi otoritas, yakni PPKI (sebagai legislator pertama secara historis). Menurut Kelsen, maka dasar keabsahan dari konstitusi tersebut harus diandaikan/ diasumsikan. Apa yang diandaikan merupakan sebuah kualitas - yakni, kualitas mengikat - "ought" ("seharusnya") hukum, ialah norma dasar. Karena legislator pertama secara historis dianggap sebagai otoritas hukum tertinggi, maka "norma" yang memberi otoritas tidak bisa ditetapkan melalui tindakan kehendak manusia; menurut positivisme hukum, tidak ada otoritas "di atas" legislator pertama secara historis. Jika norma yang memberi otoritas tidak bisa menjadi norma yang ditetapkan (norma gesetzt) maka ia menjadi norma yang diandaikan (vorausgesetzt) dalam pemikiran yuridis, ungkap Kelsen.

${ }^{25}$ Kelsen, General Theory. 1945, hal. 116.
} 
religious ideas which the constitution is intended to promote. This preamble usually does not stipulate any definite norms for human behavior and thus lacks legally relevant contents. It has an ideological rather than a juristic character. "26

"Satu bagian tradisional dari instrumen yang disebut "konstitusi" merupakan sebuah pengantar yang hikmad, disebut "pembukaan" yang menyatakan ide-ide politik, moral, dan keagamaan yang hendak dimajukan konstitusi tersebut. Pembukaan ini lazimnya tidak menetapkan sesuatu norma tertentu bagi perilaku manusia dan dengan demikian kurang memiliki isi yang relevan menurut hukum. Pembukaan ini lebih mempunyai karakter ideologi daripada karakter hukum."

Bertolak dari kutipan Kelsen tersebut, sila-sila dari Pancasila di dalam Pembukaan UUD 1945 sebenarnya mempunyai karakter ideologi, yakni, ideologi negara dan bangsa Indonesia; karena di dalam "Pembukaan" tersebut, selain terdapat cita-cita dan tujuan-tujuan yang hendak diupayakan direalisasikan, juga terdapat prinsip - prinsip yang diterapkan mungkin dievaluasi. Karena itu, Pembukaan qua hukum yang lebih tinggi ini berakar pada prinsip-prinsip yang kekal dan abadi. Dengan demikian, sila - sila dari Pancasila di dalam Pembukaan UUD 1945 bisa disebut sebagai "hukum kodrat" (natural law) dan ia muncul sebagai faktor utama dalam pembentukan UUD 1945.

Tetapi dalam Pure Theory of Law, 1967, Kelsen menyatakan penolakannya terhadap teori hukum kodrat, yakni terhadap keberadaan isi ("substance" atau “content”) dari norma hukum. Kelsen mengatakan norma dasar [Grundnorm] dari suatu tertib hukum bukan norma material tertentu yang karena isinya dianggap terbukti sendiri (self-evident). Dengan demikian, sebuah norma hukum dari suatu sistem norma tertib hukum tertentu tidak sah karena mempunyai isi tertentu, yakni karena isinya dapat dideduksi secara logis dari norma tertinggi suatu kesatuan. ${ }^{27}$

Ketidaksukaan Kelsen terhadap teori hukum kodrat tersebut telah muncul ketika Kelsen mulai mengembangkan Teori Murni Hukum. ${ }^{28}$ Karena itu, upaya Kelsen menolak hukum kodrat bukan menjadi sesuatu yang mengherankan, misalnya di dalam Introduction to the Problems of Legal Theory, sebuah karya

\footnotetext{
${ }^{26}$ Kelsen, General Theory. 1945, hal. 260-261.

${ }^{27}$ Kelsen, Pure Theory. 1967, hal. 198.

${ }^{28}$ Paulson, "Review: Four Phases," hal. 153-166.
} 
yang pertama kali muncul 1934, Kelsen dengan tegas menyatakan penolakannya terhadap hukum kodrat (natural law) sebagai dasar keabsahan hukum positif, tetapi meskipun demikian hukum positif dipahami sebagai sistem sah, yakni, sebagai norma dan tidak hanya sebagai kemungkinan faktual dari motivasi. ${ }^{29}$ Penolakan terhadap hukum kodrat tersebut kembali dinyatakan dalam karya Kelsen, General Theory of Law and State, 1945; ketika, Kelsen menyatakan penolakannya dengan tidak mau mengakui keabsahan norma hukum positif bersumber pada hukum kodrat. ${ }^{30}$

Dalam konteks inilah, Kelsen secara tegas menolak teori "Murni” dijadikan ilmu metafisika hukum. Kelsen menyatakan bahwa ilmu hukum tradisional dicirikan oleh suatu kecenderungan mengacaukan dengan mencampuradukkan teori hukum positif dengan ideologi - ideologi politik yang telah disamarkan baik sebagai spekulasi metafisika mengenai keadilan maupun sebagai doktrin hukum kodrat. Karena itu, teori "Murni" mencari fondasi hukum, tidak dalam sebuah prinsip meta-juristic (prinsip meta - hukum), melainkan dalam suatu hipotesis yuridis. Teori "Murni" menolak dasar keabsahan dari hukum kodrat menjadi fokus perhatiannya, karena itu norma dasar dari hukum kodrat yang bersifat kategoris harus dikesampingkan, sedangkan dasar keabsahan dari sistem hukum positif harus merupakan sebuah norma dasar yang dibuat berdasarkan sebuah analisis logis terhadap pemikiran yuristis yang aktual. ${ }^{31}$

Kelsen berpendapat bahwa dalam pandangan doktrin hukum kodrat tradisional, suatu tertib hukum positif hanya sah (valid) hanya jika isinya berkorespondensi dengan hukum kodrat (natural law); ini berbeda dengan teori norma dasar Kelsen, kandungan (isi) norma dari tertib hukum positif itu sama sekali terlepas dari norma dasar dari mana keabsahan obyektif tertib hukum ini tersebut berasal. Dengan demikian, dari pandangan Kelsen kemungkinan konflik antara tertib hukum positif dengan norma dasarnya, tidak pernah terjadi;

\footnotetext{
${ }^{29}$ Hans Kelsen, Introduction to The Problems of Legal Theory. Diterjemahkan oleh Bonnie Litschewski Paulson and Stanley L. Paulson, dengan "Kata Pengantar" oleh Stanley L. Paulson. Oxford: Clarendon Press, 1992. hal. 58 .

${ }^{30}$ Kelsen, General Theory. 1945, hal. 115.

${ }^{31}$ Kelsen, General Theory. 1945, hal. xv.
} 
sementara itu dari pandangan teori positivistis hukum masih dimungkinkan terjadinya konflik antara hukum positif dan yang diandaikan sebagai hukum kodrat. $^{32}$ Berarti norma dasar yang diajukan Kelsen, harus sedemikian rupa sehingga hukum positif tidak bisa bertentangan dengan dasar itu. Untuk itu, dasar keabsahan itu harus kosong dari isi dan hanya merujuk kepada dinamika hukum. ${ }^{33}$

Dengan mengacu kepada penjelasan yang diberikan Kelsen ini, tidaklah tepat bagi Roeslan Saleh dan A. Hamid S. Attamimi mengkonstruksi Pancasila sebagai norma dasar [Grundnorm] dalam tertib hukum Indonesia. Karena doktrin Kelsen mengenai norma dasar sebagai norma tertinggi dan terakhir dari suatu tertib hukum tidak pernah dapat memiliki elemen statis. Sedangkan Pancasila yang ditafsirkan sebagai norma dasar [Grundnorm] itu memiliki sifat yang sepenuhnya statis. Penolakan Kelsen terhadap hukum kodrat sebagai dasar keabsahan hukum positif, telah meneguhkan pandangan bahwa Pancasila bukan qua [sebagai] norma dasar [Grundnorm] dari Kelsen. Pendek kata, pendapat dari kedua ilmuwan hukum tersebut tidak cermat mengkonstruksi Pancasila sebagai doktrin norma dasar [Grundnorm] Kelsen.

Kembali kepada pandangan Kelsen, hukum sebagai sistem norma-norma yang disebut tertib hukum merupakan sistem dinamis. Dalam sistem dinamis ini, norma-norma hukum tidak sah karena norma dasar mempunyai suatu isi (content) yang kekuatan mengikatnya self-evident (terbukti sendiri). Berbeda halnya dengan sistem statis, seperti misalnya norma moralitas, nampaknya keabsahan norma-norma tersebut dideduksi dari norma dasar yang self-evident karena dianggap sebagai pernyataan dari "will of nature" atau "pure reason." Bagi Kelsen, norma dasar suatu tertib hukum positif tidak lain merupakan peraturan fundamental mengenai penciptaan berbagai norma dari tertib hukum positif tersebut. Norma dasar inilah merupakan titik awal dari proses pembentukan norma dan, oleh karena itu norma dasar dalam tertib hukum memiliki karakter

\footnotetext{
${ }^{32}$ Kelsen, Pure Theory. 1967. hal. 62.

${ }^{33}$ Bindreiter, Why Grundnorm? 2002, hal. 22., menyatakan norma dasar [Grundnorm] dari sebuah tertib hukum positif - kosong dari isi - atau dalam bahasa Kelsen: seseorang bisa berbicara mengenai isi sehubungan dengan norma dasar, isinya tidak lain "penentuan sebuah fakta penciptaan norma, otorisasi dari sebuah pencipta - norma atau sebuah aturan yang menyatakan bagaimana norma umum dan norma individual dari tertib tersebut didasarkan pada norma dasar tersebut diciptakan.
} 
yang sepenuhnya dinamis. Norma - norma tertentu diciptakan oleh tindakan kehendak tertentu, tidak disimpulkan dari premis oleh suatu cara kerja intelektual.

Dalam teori Kelsen, pembedaan prinsip statis dan prinsip dinamis ini bisa diartikan bahwa norma dasar dari suatu tertib hukum tidak dapat statis. Tetapi, Kelsen pada fase skeptisnya menyatakan bahwa dirinya tidak pernah mengatakan bahwa suatu tertib hukum tersebut tidak dapat statis, ${ }^{34}$ tetapi ia terang-terangan menyatakan bahwa norma dasar dari tertib hukum positif memiliki sifat yang sepenuhnya dinamis. Bertolak dari pernyataan tersebut, norma dasar [Grundnorm] tidak dapat ditafsirkan sebagai Pancasila seperti ditempuh Roeslan Saleh dan A. Hamid S. Attamimi, karena Pancasila hanya memiliki sifat yang sepenuhnya statis. Tetapi Kelsen dalam The Pure Theory of Law, 1967 memberikan penekanannya bahwa prinsip statis pada gilirannya memperoleh akses kepada sistem hukum positif. ${ }^{35}$ Bertolak dari pernyataan Kelsen ini, maka Pancasila hanya memiliki akses pada sistem hukum positif dan bukan sebagai norma dasar [Grundnorm] dalam sistem norma hukum Indonesia, seperti diklaim kedua ilmuwan hukum tersebut. Kelsen menjelaskan pernyataan tersebut sebagai berikut:

"The constitutional legislator does not determine merely organs for legislation, but also a legislative procedure; and, at times his norms, that is the constitution (in the sense of positive law), determine in the so-called fundamental rights and bills of liberty the content of the laws, when they prescribe a minimum of what they and should not contain. "36

"Legislator konstitutional tidak menentukan hanya organ untuk legislasi, melainkan juga prosedur legislative; dan, terkadang norma-normanya, yaitu konstitusi (dalam pengertian hukum positif), menentukan isi dari hukum hak-hak azasi dan piagam kebebasan, ketika mereka mempreskripsikan apa yang harus dan tidak boleh dimuat dalam hukum tersebut."

"The static and dynamic principles are contained in one and the same system of positive norms, if the presupposed basic norm, according to the dynamic principle, only authorizes a norm creating authority, and if this authority and authorities instituted by it establish not only norms which

\footnotetext{
${ }^{34}$ Hans Kelsen, "Professor Stone and the Pure Theory of Law," Stanford Law Review, Vol. 17, No. 6 (Jul., 1965), hal. 1146.

${ }^{35}$ Kelsen, "Professor Stone," 1965, hal. 1146-1147.

${ }^{36}$ Kelsen, General Theory. 1945, hal. 401.
} 
delegate other norm-creating authorities but also norm prescribing a definite behavior of individuals subjected to norms. ${ }^{37}$

"Prinsip statis dan dinamis terkandung dalam satu sistem norma positif yang sama jika norma dasar yang diandaikan, menurut prinsip dinamis, hanya memberikan otoritas kepada otoritas pembuat norma, dan jika otoritas ini dan otoritas - otoritas yang dilembagakan olehnya menetapkan tidak hanya norma yang mendelegasikan otoritas - otoritas pembuat norma lain melainkan juga norma yang mempreskripsikan tingkah laku tertentu dari individu-individu yang tunduk kepada norma tersebut.

Pernyataan Roeslan Saleh pada poin 1, catatan kaki no. 16 di atas menunjukkan bahwa Pancasila qua Grundnorm versi Roeslan Saleh dimaksudkan sebagai suatu konsepsi yang dikonstruksi memiliki pemahaman yang lebih luas daripada Grundnorm dari Kelsen. Bagi Roeslan Saleh Grundnorm Pancasila tidak hanya meliputi suatu tertib hukum, tetapi juga terdiri dari norma-norma moral. Dengan demikian, Pancasila qua Grundnorm merupakan konstruksi dari ketunggal - ikaan dalam ke-bhineka-an norma - norma. Ini berarti, Roeslan Saleh hendak menunjukkan kepada kita bahwa susunan tertib hukum dan tertib moral di Indonesia sekalipun berbeda tetapi keduanya tidak dapat dipisahkan satu sama lain. Berbeda halnya dengan teori Murni Kelsen, yang sejak awal pada fase klasiknya pertama kali diperkenalkan berupaya memisahkan hukum dan moral.

Pernyataan Roeslan Saleh ini menunjukkan ketidakpahamannya terhadap teori norma dasar Kelsen. Karena norma dasar dari tertib hukum positif memiliki sifat yang sepenuhnya dinamis. Roeslan Saleh menggunakan dasar pemikiran dan metode yang tidak tepat ketika mengkonstruksi Pancasila qua Grundnorm dalam tertib hukum Indonesia. Karena Roeslan Saleh menggunakan syncretic union (kombinasi prinsip statis dan dinamis) dalam membangun tertib hukum Indonesia; sebuah langkah yang menyatukan hukum dan moral dengan puncaknya Pancasila sebagai norma dasar [Grundnorm] dari Kelsen. Dengan demikian, langkah-langkah yang ditempuh Roeslan Saleh menyatukan hukum dan moral dalam tertib hukum Indonesia dengan menggunakan syncretic union

\footnotetext{
${ }^{37}$ Kelsen, Pure Theory. 1967. hal. 197-198.
} 
(kombinasi prinsip statis dan dinamis) tidak sejalan dengan doktrin norma dasar Kelsen, pasti berakhir dengan suatu kegagalan.

Kelsen kembali menegaskan bahwa norma dasar [Grundnorm] tersebut tidak diciptakan / ditetapkan oleh kehendak yang real (nyata) dari organ hukum, melainkan hanya diandaikan oleh pemikiran yuristis. ${ }^{38}$ Kelsen memformulasikan norma dasar itu, yakni, sebuah norma yang diandaikan jika makna subyektif dari fakta penciptaan konstitusi dan makna subyektif dari fakta penciptaan norma tersebut ditetapkan berdasarkan konstitusi dan diinterpretasikan sebagai makna obyektifnya. Karena itu, norma dasar dari suatu tertib hukum (yaitu, suatu tertib yang menetapkan tindakan paksaan) harus dirumuskan sebagai berikut:

"Coersive acts sought to be performed under the conditions and in the manner which the historically first constitution, and the norms created according to it, prescribe. (In short: One ought to behave as the constitution prescribes.) The norms of a legal order, whose common reason for their validity is this basic norm are not a complex of valid norms standing coordinatedly side by side, but form a hierarchical structure of super and subordinate norms. "39

"Tindakan paksaan akan dilaksanakan berdasarkan kondisi dan cara yang ditetapkan oleh konstitusi pertama secara historis, dan norma yang diciptakan sesuai dengannya (Pendek kata: kita seharusnya bertingkah laku sebagaimana ditetapkan oleh konstitusi). Norma-norma dari suatu tertib hukum, yang alasan umum keabsahannya adalah norma dasar ini bukanlah suatu kompleks norma-norma sah berdiri berdampingan secara sederajad, tetapi bentuk struktur hierarkhis dari norma yang superordinat dan subordinat."

\section{Kesimpulan}

Dapat disimpulkan bahwa norma dasar [Grundnorm] harus memenuhi sejumlah kondisi sebagai berikut ini: Pertama, norma dasar (atau, dasar

\footnotetext{
${ }^{38}$ Kelsen, Pure Theory. 1967, hal. 9-10, 23., menyatakan: "Finally it is to be noted that a norm need not be only the meaning of a real act of will; it can also be the content of an act of thinking. This is the case if the norm is only presupposed in our thinking. Just as we can image things which do not really exist but "exist" only of our thinking, we can image a norm which is not the meaning of a real of will but which exists only in our thinking. Then, it is not a positive norm. But since there is a correlation between the ought of a norm and a will whose meaning it is, there must be in our thinking also an imaginary will whose meaning is the norm which is only presupposed in our thinking - as is the basic norm of a positive legal order." Bandingkan dengan Kelsen, Legal Theory. 1992, hal. 29; Kelsen, General Theory. 1945, hal. 116; Kelsen, Pure Theory. 1967, hal. 199.

${ }^{39}$ Kelsen, Pure Theory. 1967, hal. 200-201.
} 
keabsahan) harus merupakan sebuah norma non-positif, yakni bukan norma yang “ditetapkan". Kedua, norma dasar bukan hukum kodrat dan harus berbeda dari dasar hukum kodrat. Karena norma dasar dari hukum kodrat bersifat kategoris, sedangkan dasar keabsahan dari sistem hukum positif itu harus bersifat hipotetis, yakni norma dasar diandaikan jika kondisi-kondisi tertentu terpenuhi. Ketiga, norma dasar itu memberikan keabsahan obyektif kepada norma-norma dari konstitusi (positif) tanpa terikat kepada isi dari norma-norma tersebut. Jadi, norma dasar harus kosong dari isi dan merujuk kepada dinamika hukum sehingga norma dasar tidak berbahaya bagi hukum positif. Keempat, norma dasar harus memberikan otoritas penciptaan norma-norma positif tertinggi (konstitusi pertama secara historis) dari sistem hukum dan memberi konstitusi dan norma-norma yang berasal dari konsitusi itu dengan kekuatan mengikat. Dengan demikian, norma dasar itu harus menutup hirarkhi norma dan menjadi titik tolak bagi prosedur penciptaan hukum.

Keempat kondisi norma dasar Kelsen ini tidak dipenuhi oleh Roeslan Saleh dan A. Hamid S. Attamimi, sehingga upaya mengkonstruksi kedudukan Pancasila dalam sistem norma hukum Indonesia tidak menjustifikasi klaimnya bahwa Pancasila merupakan suatu Grundnorm di dalam Pembukaan UUD 1945. Pendek kata, kedudukan Pancasila di dalam Pembukaan UUD 1945 telah ditafsirkan secara tidak teliti sebagai norma dasar [Grundnorm] dari Kelsen. Dengan demikian, berbagai upaya yang telah ditempuh ketika mengkonstruksi Pancasila qua Grundnorm dengan mendasarkan pada doktrin norma dasar Kelsen merupakan langkah yang sia - sia karena itu tidak dapat diterapkan dalam sistem norma hukum Indonesia. Makalah ini telah membuktikan prestasinya kedua ilmuwan hukum tersebut tidak dapat dipertahankan sehingga kita tidak dapat memetik manfaat dari upaya yang telah ditempuhnya bagi pengembangan ilmu hukum di Indonesia. 


\section{DAFTAR PUSTAKA}

Asshiddiqie, Jimly. Komentar Atas Undang-Undang Dasar Negara Republik Indonesia Tahun 1945. Jakarta: Sinar Grafika, 2009.

Attamimi, Abdul Hamid Saleh. "UUD 1945 - TAP MPR - Undang-undang Kaitan Norma Hukum Ketiganya," Masalah Ketatanegaraan Indonesia Dewasa Ini, dihimpun oleh Padmo Wahjono. Jakarta: Ghalia Indonesia, 1985.

."Peranan Keputusan Presiden Republik Indonesia dalam Penyelenggaraan Pemerintahan Negara: Suatu Studi Analisis Mengenai Keputusan Presiden yang Berfungsi Pengaturan dalam Kurun Waktu Pelita I - Pelita IV." Disertasi Fakultas Pascasarjana Universitas Indonesia, 1990.

Bindreiter, Uta U., "Presupposing the Basic Norm," Ratio Juris. Vol. 14, No. 2 (June., 2001), hal. 143-175.

.Why Grundnorm? A Treatise on the Implications of Kelsen's Doctrine, Hague, London, New York: Kluwer Law International, 2002.

Bulygin, Eugeno. “An Antinomy in Kelsen's Pure Theory of Law," Normativity and Norms: Critical Perpectives in Kelsen Themes, eds. Stanley L. Paulson and Bonnie Litschewski Paulson. Oxford: Clarendon Press, 1998.

Edel, Geert. "The Hypothesis of the Basic Norm: Hans Kelsen and Hermann Cohen," Normativity and Norms: Critical Perspectives on Kelsenian Themes, eds. Paulson, Stanley L dan Bonnie Litschewski Paulson. Oxford: Clarendon Press, 1998.

Kelsen, Hans. .Introduction to The Problems of Legal Theory. Terjemahan edisi pertama dari Reine Rechtslehre. Einleitung in die Rechtswissenschaftliche Problematik, Vienna, Franz Deuticke, 1934. [atau Pure Theory of Law]. Diterjemahkan oleh Bonnie Litschewski Paulson and Stanley L. Paulson, dengan "Kata Pengantar" oleh Stanley L. Paulson. Oxford: Clarendon Press, 1992.

.General Theory of Law and State. Diterjemahkan oleh: Anders Wenderg. New York: Russell \& Russell, 1945. 
.Professor Stone and the Pure Theory of Law," Stanford Law Review, Vol. 17, No. 6 (Jul., 1965), hal. 1128-1157.

.Pure Theory of Law. Terjemahkan dari Reine Rechtslehre, Vienna, Verlag Franz Deuticke, 1960. (Direvisi dan Diperluas dari edisi pertama). Diterjemahkan oleh Max Knight, Berkeley, Los Angeles, London: University of California Press, 1967.

Koesnoe, Moh. "Perumusan dan Pembinaan Cita Hukum dan Azas-azas Hukum Nasional," Majalah Hukum Nasional, Badan Pembinaan Hukum Nasional, Departemen Kehakiman, No. 2, 1995, hal. 70-118.

Paulson, Stanley L. "Introduction," dalam Hans Kelsen, Introduction to The Problems of Legal Theory. Terjemahan Edisi Pertama dari Reine Rechtslehre atau [Pure Theory of Law]. Diterjemahkan oleh: Bonnie Litschewski Paulson and Stanley L. Paulson, dengan Kata Pengantar oleh Stanley L. Paulson. Oxford: Clarendon Press, 1992.

."Review: Four Phases in Hans Kelsen's Legal Theory? Reflections on a Periodization," Oxford Journal of Legal Studies, Vol. 18, No. 1 (Spring, 1998), hal. 153-166.

Paulson, Stanley L dan Bonnie Litschewski Paulson, Ed. Normativity and Norms: Critical Perspectives on Kelsenian Themes. Oxford: Clarendon Press, 1998.

Reck, Andrew J. "Natural law and the Constitution," The Review of Metaphysics, Vol. 42, No. 3, Mar., 1989, hal. 485.

Saleh, Roeslan. Penjabaran Pancasila dan UUD'45 dalam Perundang-undangan. Jakarta, Aksara Baru, 1979.

."Pembinaan Cita Hukum dan Penerapan Azas-Azas Hukum Nasional," Majalah Hukum Nasional, Edisi Khusus, No. 1, 1995, hal. 42-90.

Schmill, Ulises, "The Dynamic Order of Norm. Empowerment and Related Concepts," Law and Philosophy, Vol. 19, No. 2, Kelsen, Authority and Competence (Mar., 2000), hal. 263-310.

Singh, Chhatrapati. Law from Anarchy to Utopia. Oxford: Clarendon Press, 1986. 
22 ADIL : Jurnal Hukum Vol. 3 No.1

Soekarno, Pancasila sebagai Dasar Negara. Jakarta: Diterbitkan atas Kerja sama Inti Idayu Press - Yayasan Pendidikan Soekarno, 1986,

Yamin, Muh. Naskah Persiapan Undang-Undang Dasar 1945. Jilid Pertama. Jakarta: Prapanca, 1959. 